\title{
Phosphorus budget of Apalachicola Bay: a river-dominated estuary in the northeastern Gulf of Mexico
}

\author{
Behzad Mortazavi ${ }^{1, *}$, Richard L. Iverson ${ }^{1}$, William M. Landing ${ }^{1}$, Wenrui Huang ${ }^{2}$ \\ 'Florida State University, Department of Oceanography, Tallahassee, Florida 32306-4320, USA \\ ${ }^{2}$ FAMU-FSU College of Engineering, 2525 Pottsdamer St., Tallahassee, Florida 32310-6046, USA
}

\begin{abstract}
Estuarine nutrient budgets are used to understand the transformation of river-born nutrients delivered to the sea, and to gain insights into the impact of terrestrially-derived nutrients on coastal ecosystems. To construct a phosphorus budget for Apalachicola Bay, we measured soluble reactive, dissolved organic, and particulate phosphorus in the Apalachicola River and estuary on a monthly basis over a 2 yr period. The results of the chemical time-series measurements were coupled with river flow data and results of a 3-dimensional hydrodynamic model of the estuary to estimate phosphorus input to the estuary and phosphorus exchange with the Gulf of Mexico (GOM). On average, the Apalachicola River accounted for 70 and $78 \%$ of the water and total phosphorus (TP) input to the estuary. respectively, while exchange with the GOM accounted for the remainder. TP input to the estuary was $4.57 \pm 0.21$ ( $\pm 1 \mathrm{SD}) \mathrm{g} \mathrm{P} \mathrm{m}^{-2} \mathrm{yr}^{-1}$, the majority of which was in the particulate form $\left(2.69 \pm 0.19 \mathrm{~g} \mathrm{P} \mathrm{m}^{-2} \mathrm{yr}^{-1}\right)$. Dissolved organic phosphorus (DOP) represented $24 \%$ of the total input, while soluble reactive phosphorus (SRP) represented the smallest fraction (17\%) of the total input. Particulate phosphorus export to the GOM $\left(2.75 \pm 0.19 \mathrm{~g} \mathrm{P} \mathrm{m}^{-2} \mathrm{yr}^{-1}\right)$ was similar to particulate phosphorus input to the estuary. However, only 64 and $58 \%$ of the DOP and SRP input to the estuary, respectively, were exported to the GOM. Phosphorus accumulation in the sediments accounted for $25 \%\left(1.10 \pm 0.37 \mathrm{~g} \mathrm{P} \mathrm{m}^{-2} \mathrm{yr}^{-1}\right)$ of the TP input to the estuary. Phytoplankton phosphorus demand for the study period was $6.75 \mathrm{~g} \mathrm{P} \mathrm{m}^{-2} \mathrm{yr}^{-1}$, of which $11 \%$ could be supplied by net SRP and DOP input to the estuary. The phosphorus budget for Apalachicola Bay was balanced to within $9 \%$ of TP input.
\end{abstract}

KEY WORDS: Phosphorus - Budget - Estuary - Dissolved organic phosphorus - Soluble reactive phosphorus $\cdot$ Particulate phosphorus

\section{INTRODUCTION}

Rivers are the main source of nitrogen (Schlesinger 1997), silicate (Tréguer et al. 1995), and phosphorus (Froelich et al. 1982) input to the world ocean. River nutrient concentrations are used to estimate fluxes of these elements to the ocean (Meybeck 1982, Tréguer et al. 1995). Estuaries, located at the interface of rivers and seawater, however, are sites of intense biogeochemical processes where nutrients delivered by the

•E-mail:mortazavi@ocean.fsu.edu rivers are transformed before being carried to the sea. A correction factor is sometimes used to account for the effect of estuarine processes on the fate of river nutrients being delivered to the sea (Froelich et al. 1982). River nutrient input to estuaries occurs in inorganic, dissolved organic, and particulate forms. Inorganic nutrients are thought to be the most reactive, and frequently demonstrate a non-conservative behavior within estuaries (Kaul \& Froelich 1984, Humborg 1997). Dissolved organic nutrients, previously considered of limited biological availability, may contribute to estuarine food webs (Seitzinger \& Sanders 1997), whereas nutrients associated with particulates 
are thought to be less reactive and are readily sequestered within estuaries by sedimentation (Pennock et al. 1999). Nutrient budgets have been constructed to provide a better understanding of how nutrients impact nearshore environments (Boynton et al. 1995) and to determine the influence of estuarine processes on the net delivery of nutrients from land to the sea (Nixon et al. 1996).

Boynton et al. (1995) encouraged others to develop nutrient budgets for estuarine systems of different morphology and hydrology as aids to understanding nutrient dynamics on an ecosystem level. Nutrient budgets available for a variety of estuaries and enclosed seas have been summarized by Nixon et al. (1996). In these nutrient budget calculations, exchange at the seaward boundary has been generally estimated either by subtracting river input from internal losses with the assumption that the budget is balanced (Nixon 1987, Boynton et al. 1995, Nixon et al. 1996), or from the nutrient-salinity gradient (van Beusekom \& de Jonge 1998). In contrast to drowned-river valley or coastal plain type estuaries, where exchange with the sea occurs at only one site, bar-built estuaries exchange water and nutrients at the seaward end-member at more than one location. Depending on circulation patterns, each boundary can act as a nutrient source or sink. Therefore, it is important to measure nutrient exchange at each boundary to determine nutrient budgets for bar-built estuaries.

Nutrient budgets are generally based on either dissolved inorganic input (Nixon \& Pilson 1983), or total nitrogen or total phosphorus input (Boynton et al. 1995). However, input of dissolved nutrients underestimates, while total nutrient input overestimates, the net supply of biologically available nutrients (Seitzinger \& Sanders 1997). Shortterm experimental results, (Seitzinger \& Sanders 1997) suggest that in estuaries with residence times of days to weeks, net retention of dissolved organic nitrogen (DON) is insignificant. A nitrogen budget for Apalachicola Bay indicated that DON input to the estuary and export to the Gulf of Mexico (GOM) were balanced (Mortazavi et al. 2000a). Information on dissolved organic phosphorus (DOP) retention within estuaries, however, is lacking.

Our. góals in this study were 2 -fold. First, we wished to construct a phosphorus budget for Apalachicola Bay, a short residence-time, bar-built estuary in the northeastern GOM, and to evaluate phosphorus exchange with the Gulf. Our second goal was to examine net DOP reten- tion within the estuary. We combined the output from a 3-dimensional, hydrodynamic circulation model with monthly monitoring of phosphorus concentrations in the Apalachicola River and estuary to determine the riverine input and exchanges at marine end-member locations of soluble reactive phosphorus (SRP), DOP, and particulate phosphorus (Part P).

\section{METHODS}

Study site. Apalachicola Bay, with an area of $260 \mathrm{~km}^{2}$, is a shallow (mean depth $2.2 \mathrm{~m}$ ) bar-built estuary that receives freshwater from the Apalachicola River (Fig. 1). The Apalachicola River, the third largest river in terms of flow in the northern GOM (Bianchi et al. 1999), is formed by: the confluence of the Chattahoochee and Flint rivers. The Apalachicola-Chattahoochee-Flint (ACF) drainage basin, with an area of $45000 \mathrm{~km}^{2}$ (Fu \& Winchester 1994), is situated in the states of Georgia $(78 \%)$, Alabama (10\%), and Florida (12\%) (Huang \& Jones 1997). The estuary exchanges water with the GOM through St. George Sound, West Pass, and Indian Pass. Bob Sikes Cut (Fig. 1), an artificial pass, accounts for only minor water exchange with the GOM. Livingston (1984) has considered the Apalachicola River watershed to be one of the least polluted in the USA. The estuary is an important nursery ground for a large variety of commercial fish and shellfish (Livingston 1984), and accounts for $90 \%$ of Florida's oyster harvest (Wilber 1992).

Hydrodynamic circulation model. Apalachicola Bay water exchange with the GOM was determined with a 3-dimensional, time-dependent, numerical hydrody-

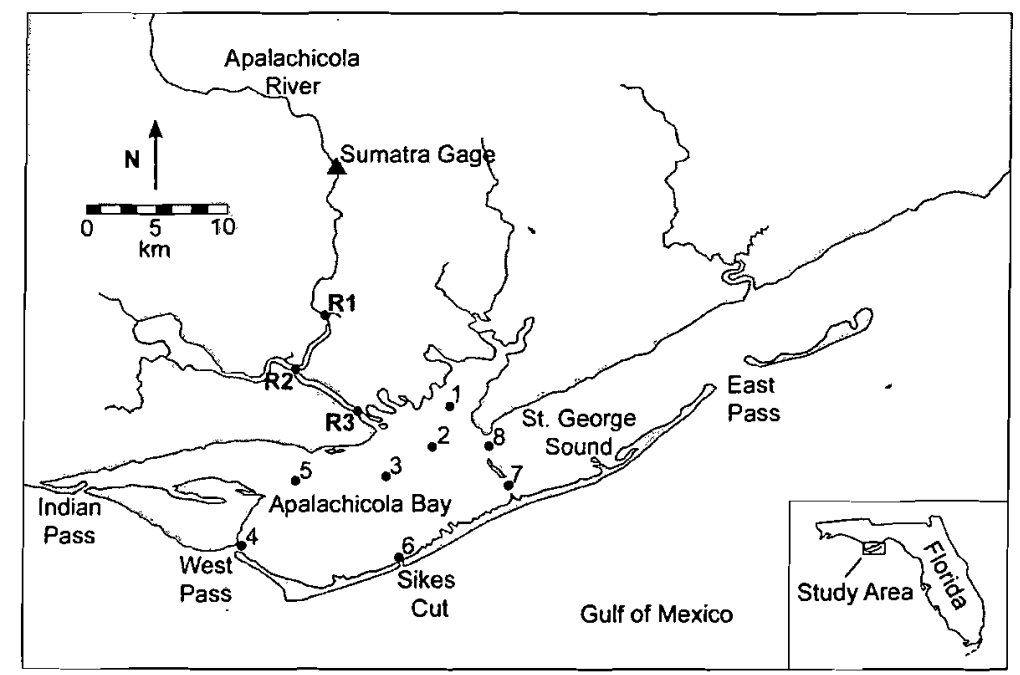

Fig. 1. Map of Apalachicola River and estuary, River flow was measured at the Sumatra gage. River samples were collected at Stations R1, R2, and R3, estuarine samples were collected at Stations 1 through 8 
namic model that allowed velocity, temperature and salinity field-calculations (Jones \& Huang 1996). A Blumberg \& Mellor $(1980,1987)$ model application to Apalachicola Bay used an explicit-in-horizontal, implicitin-vertical, finite-difference format, with forcing by freshwater inflow, tide, and wind stress. The set of governing equations is given by Blumberg \& Herring (1987). The model solved a coupled system of differential, prognostic equations describing conservation of mass, momentum, heat, and salinity at each of 930 horizontal grids and 5 vertical layers of the computational scheme (Huang \& Jones 1997). A horizontal, orthogonal, curvilinear coordinate system allowed representation of coastline irregularities. A sigma coordinate system allowed vertical stretching to simulate water-level changes in the estuary. A turbulence closure submodel (Mellor \& Yamada 1982, Galperin et al. 1988), that provides eddy viscosity and eddy diffusivity for vertical mixing, permitted variation in the forcing factors (Huang \& Jones 1997). This type of model has been successfully applied to other estuaries, including Chesapeake Bay (Blumberg \& Goodrich 1990) and Delaware Bay (Galperin \& Mellor 1990).

The hydrodynamic model for Apalachicola Bay was calibrated and validated with hydrographic data recorded at $0.5 \mathrm{~h}$ intervals by instruments located throughout the estuary, during a 6 mo period (Huang \& Jones 1997). For simulations used in the present analysis, measured river discharge, winds, tides, temperature, and salinity were applied to the model as boundary conditions. The model was used to calculate water inflow and export at the passes. River-flow data, provided by Northwest Florida Water Management District, were measured at the Sumatra gage, $32 \mathrm{~km}$ upstream of the river mouth (Fig. 1).

Sample collection and chemical analysis. Beginning in 1994, surface-water samples were obtained at 3 river stations, and both surface and bottom-water samples were obtained at 8 estuarine stations (Fig. 1) on a monthly basis for 2 consecutive years. Water samples were stored in acid-washed polyethylene bottles and kept on ice in the dark during each cruise. A portion of each sample was filtered through GF/F filters at a laboratory adjacent to Apalachicola Bay, and stored for transfer to Florida State University. Within $24 \mathrm{~h}$ of sample collection, SRP concentrations were determined with the molybdenum blue method, as described by Strickland \& Parsons (1972). Total dissolved phosphorus (TDP) and total phosphorus (TP) were measured following autoclave/persulfate oxidation (Greenberg et al. 1992), with phosphorus concentrations determined as described previously for SRP. DOP concentration was calculated as the difference between total dissolved and soluble-reactive phosphorus values measured for the same sample. Part P concentrations were determined as the difference between total unfiltered and total filtered phosphorus values. Nutrient fluxes at each boundary were determined by multiplying the concentrations by the appropriate water-flow rate.

Estimates of annual nutrient input to estuaries are commonly based on monthly or biweekly monitoring of river nutrient concentrations coupled with river-flow data. In a diagram of monthly input rates as a function of time, the area beneath the curve represents the integrated input for the period of time considered. The trapezoidal rule (McCracken \& Dorn 1964) was used to estimate the area beneath the curve. The height at the mid-point between 2 time intervals is used to estimate the area according to:

$$
\text { area }=\frac{\mu_{i}+\mu_{(i+1)}}{2} \cdot\left(d_{(i+1)}-d_{(i)}\right)
$$

where $\mu_{\mathrm{i}}=$ mean input rate at time $i$, and $\left(d_{(i+1)}-d_{(i)}\right)=$ time points between time period (i) and $(i+1)$.

The area underneath the curve is, therefore, a linear function of the mean input rates and can be estimated by the following function:

$$
\sum_{i=1}^{k} \mathrm{c}_{i} \bar{x}_{i}
$$

where $\bar{x}_{i}$ is the estimator of the mean input rate $(\mu)$ at time $i$ and $c_{i}$ is a constant. We assume that $\bar{x}_{i}$ has a normal distribution, with mean $\mu_{i}$ and variance $\sigma_{i}^{2} / n_{j}$, where $\sigma_{i}{ }^{2}=$ variance of observation at time $i_{\text {, and }} \mathbf{n}_{\mathrm{i}}=$ number of samples collected at time $i$. Therefore, Eq. (2) has a normal distribution, with mean $\sum_{i=1}^{k} \mathrm{c}_{i} \mu_{i}$ and variance $\sum_{i=1}^{k} \frac{\mathrm{c}_{i}{ }^{2} \sigma_{i}{ }^{2}}{\mathrm{n}_{i}}$, since $E\left(\sum_{i=1}^{k} \mathrm{c}_{i} \bar{x}_{i}\right)=\mathrm{c}_{i} \sum_{i=1}^{k} E\left(\bar{x}_{i}\right)$ and $\operatorname{var}\left(\sum_{i=1}^{k} \mathrm{c}_{i} \overline{\boldsymbol{x}}_{i}\right)=\mathrm{c}_{i}{ }^{2} \sum_{i=1}^{k} \operatorname{var}\left(\overline{\boldsymbol{x}}_{i}\right)$ for constant $\mathrm{c}_{i}$ and independent $\bar{X}_{i}$ (Montgomery 1991).

$\sigma_{i}{ }^{2}$ can be estimated by $s_{i}{ }^{2}$, where $s_{i}=$ standard deviation of the mean input rate at time $i$. Therefore, the standard deviation of the integrated input rate for 2 time points can be determined according to:

$$
\sqrt{\sum_{i=1}^{k} \frac{\mathrm{c}_{i}^{2} s_{i}^{2}}{\mathrm{n}_{i}}}
$$

Standard deviations of phosphorus input rates for Apalachicola River and input through St. George Sound were determined according to Eq. (3). Because limited samples were collected at West Pass, Indian Pass, and Bob Sikes Cut, the standard deviations (SD) in the annual budget for phosphorus exchange at these sites were determined by applying the relative SD of the mean exchange rate at St. George Sound. 


\section{RESULTS}

\section{Hydrology}

The long-term (1965 to 1989) monthly Apalachicola River discharge, monitored at the Sumatra gage, exhibits strong seasonality (Fig. 2). Discharge maxima occurred in winter and early spring in response to increased rainfall over the ACF watershed. Periods of low river flow are characteristic of the summer and fall seasons. Data obtained during the $2 \mathrm{yr}$ study of the Apalachicola River and estuary spanned the long-term Apalachicola River flow range (Fig. 2). Average river flow for the study period was $888 \mathrm{~m}^{3} \mathrm{~s}^{-1}$, slightly higher than the longterm monthly mean discharge of $710 \mathrm{~m}^{3} \mathrm{~s}^{-1}$ (Fu \& Winchester 1994). Cruises in 1995 were preceded by river flow close to the long-term discharge rates. This contrasts with 1994, when discharge patterns were generally below average flow rates in winter and greater during the summer and fall seasons (Fig. 2). Maximum river flow $\left(2780 \mathrm{~m}^{3} \mathrm{~s}^{-1}\right)$ was measured in July 1994 in response to several low-pressure atmospheric systems that caused unusually high rainfall over the watershed. Following the flood event, river flow remained high until October 1994 before resuming normal flow patterns. Minimum river flow $\left(334 \mathrm{~m}^{3} \mathrm{~s}^{-1}\right)$ was measured in September 1995 (Fig. 2).

Generally, water inflow from the GOM to the estuary was lower (mean: $389 \mathrm{~m}^{3} \mathrm{~s}^{-1}$ ) than Apalachicola River water inflow, except during November 1994, and May, September, October, and December 1995 (Fig. 2). Water inflow from the GOM accounted for $30 \%$ of the total water inflow to the estuary. St. George Sound was the main source of GOM water to the estuary, and accounted for $91 \%$ of the GOM water inflow to the estuary, while Indian Pass and Bob Sikes Cut accounted for the rest. Maximum marine inflow $\left(1253 \mathrm{~m}^{3} \mathrm{~s}^{-1}\right)$ to the estuary occurred through St. George Sound in October 1995, and exceeded river flow by 2.5 times (Fig. 2). On average, $68 \%$ of the water exited the estuary through West Pass, while St. George Sound, Indian Pass and Bob Sikes Cut accounted for $18 \%, 9 \%$, and $5 \%$ of the water export to the GOM, respectively.

\section{Phosphorus concentration in river and estuary}

There were no clear seasonal trends in Apalachicola River SRP, DOP or Part P concentrations (Fig. 3). The monthly average river SRP concentration was $5.7 \pm 4.1$ $\mu \mathrm{g} \mathrm{P}^{-1}$, and varied from $1.0 \mu \mathrm{g} \mathrm{P} \mathrm{l}^{-1}$ in early 1994 to a maximum of $15 \mu \mathrm{g} \mathrm{Pl}^{-1}$ in October 1995 (Fig. 3A). DOP

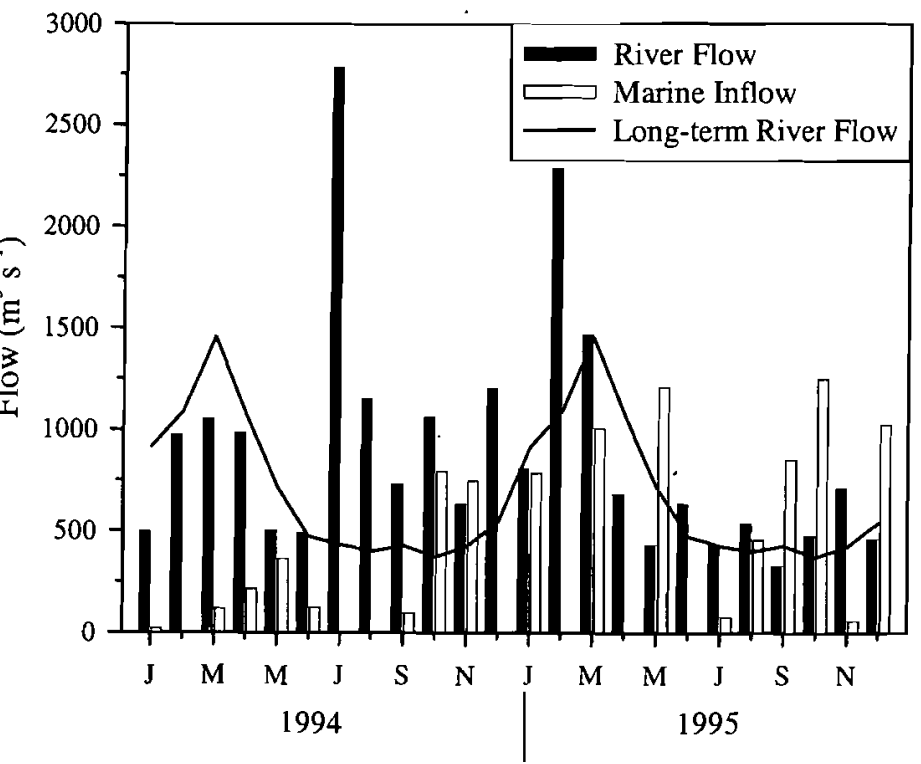

Fig. 2. Mean Apalachicola River discharge (River Flow) and Gulf of Mexico water inflow (Marine Inflow) to the estuary averaged for $5 \mathrm{~d}$ rior to each sampling. Long-term River Flow: long-term mean of discharge from Apalachicola River

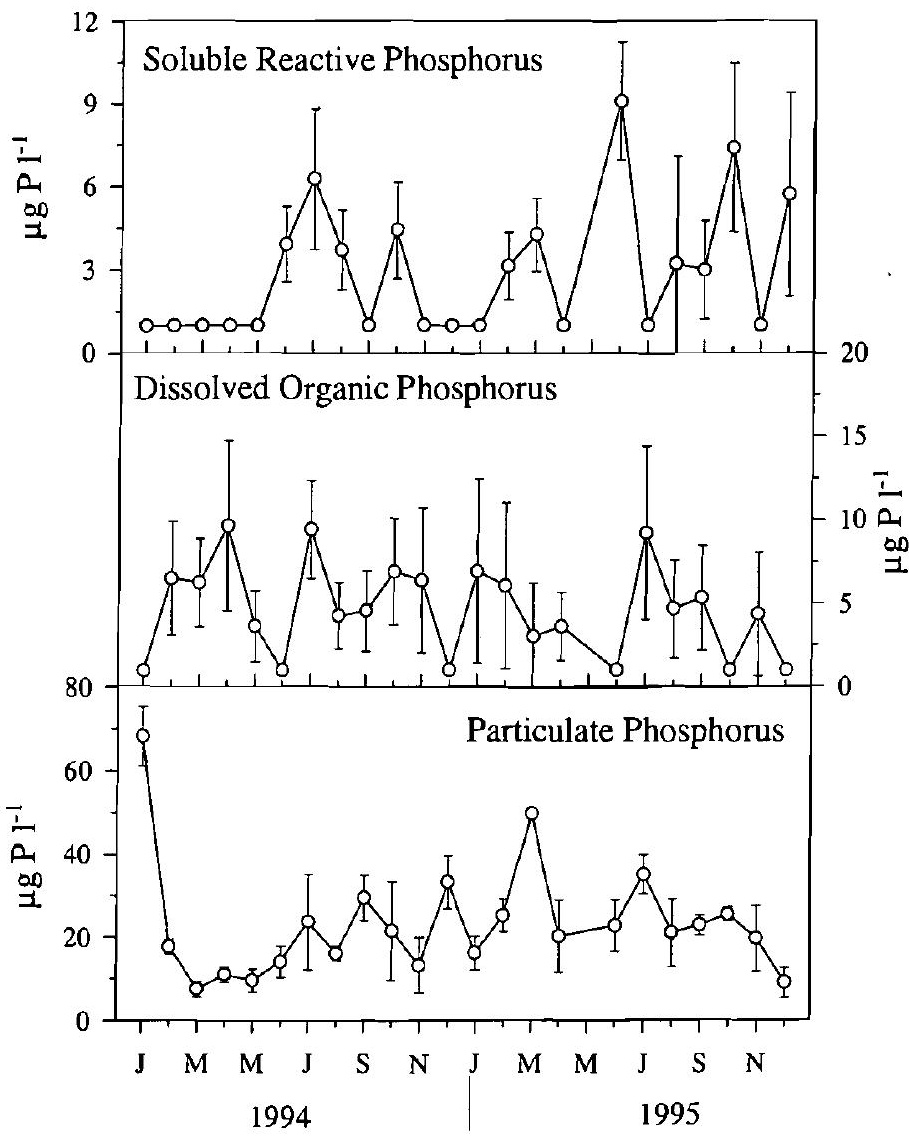

Fig. 3. Monthly mean phosphorus concentration ( $\pm 1 \mathrm{SD}$ ) for Apalachicola River over the 1994 to 1995 sampling period 
concentrations in the river varied from $1 \mu \mathrm{g} \mathrm{P} \mathrm{l}^{-1}$ in June 1995 to a maximum of $33.0 \mu \mathrm{g} \mathrm{P} \mathrm{l}^{-1}$ in January 1994 (Fig. 3). Average river DOP concentration (8.4 \pm $7.1 \mu \mathrm{g} \mathrm{P} \mathrm{l}^{-1}$ ) exceeded river SRP concentrations by 1.5 times (Fig. 3A,B). River Part $P$ concentration averaged $16.9 \pm 8.4 \mu \mathrm{g} \mathrm{Pl}^{-1}$ (Fig. 3), and represented $53 \%$ of the river TP. Greater temporal variability in Part $P$ concentration was observed relative to the river SRP or DOP concentrations. The minimum $\left(4.1 \mu \mathrm{g} \mathrm{P} \mathrm{l}^{-1}\right)$ and

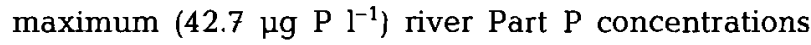
were measured in March 1994 and February 1995, respectively (Fig. 3).

SRP concentration in the estuary averaged $3.0 \pm 2.4 \mu \mathrm{g}$ $\mathrm{P} \mathrm{I}^{-1}$, slightly lower than the river SRP $\left(5.7 \pm 4.1 \mathrm{\mu g} \mathrm{Pl}^{-1}\right)$. Minimum SRP values in the estuary (Fig. 4) were measured in the 1994 winter, coincident with low river SRP concentration (Fig. 3). Maximum estuarine SRP concentration was measured in June 1995 (Fig. 4). DOP concentrations in the estuary $\left(4.6 \pm 2.8 \mu \mathrm{g} \mathrm{Pl}^{-1}\right)$ were lower than the river DOP concentrations $\left(8.4 \pm 7.1 \mu \mathrm{P} \mathrm{P}^{-1}\right)$. Minima in DOP concentrations in the estuary were measured on several occasions, generally during winter and summer seasons (Fig. 4).

Part $\mathrm{P}$ concentrations (mean $=23.1 \pm 13.7 \mu \mathrm{g} \mathrm{P}^{-1}$ ) in the estuary were higher than TDP concentration $\left(8.7 \pm 3.7 \mathrm{\mu g} \mathrm{P}^{-1}\right)$, and similar to the river Part $\mathrm{P}$ concentration $\left(16.9 \pm 8.4 \mu \mathrm{g} \mathrm{P}^{-1}\right)$. Minimum Part $\mathrm{P}$ in the estuary was measured in December 1995 (Fig. 4), when SRP concentrations were relatively high (Fig. 4). Maximum Part $P$ concentration in the estuary was measured in January 1994 (Fig. 4).

\section{Phosphorus input to estuary and export to Gulf of Mexico}

\section{Soluble reactive phosphorus}

Generally, SRP input to the estuary was low during summer and fall seasons (Fig. 5). However, maximum SRP input of $7.0 \mathrm{mg} \mathrm{P} \mathrm{m}^{-2} \mathrm{~d}^{-1}$ to the estuary occurred during the July 1994 flood (Fig. 5). The greatest frac-

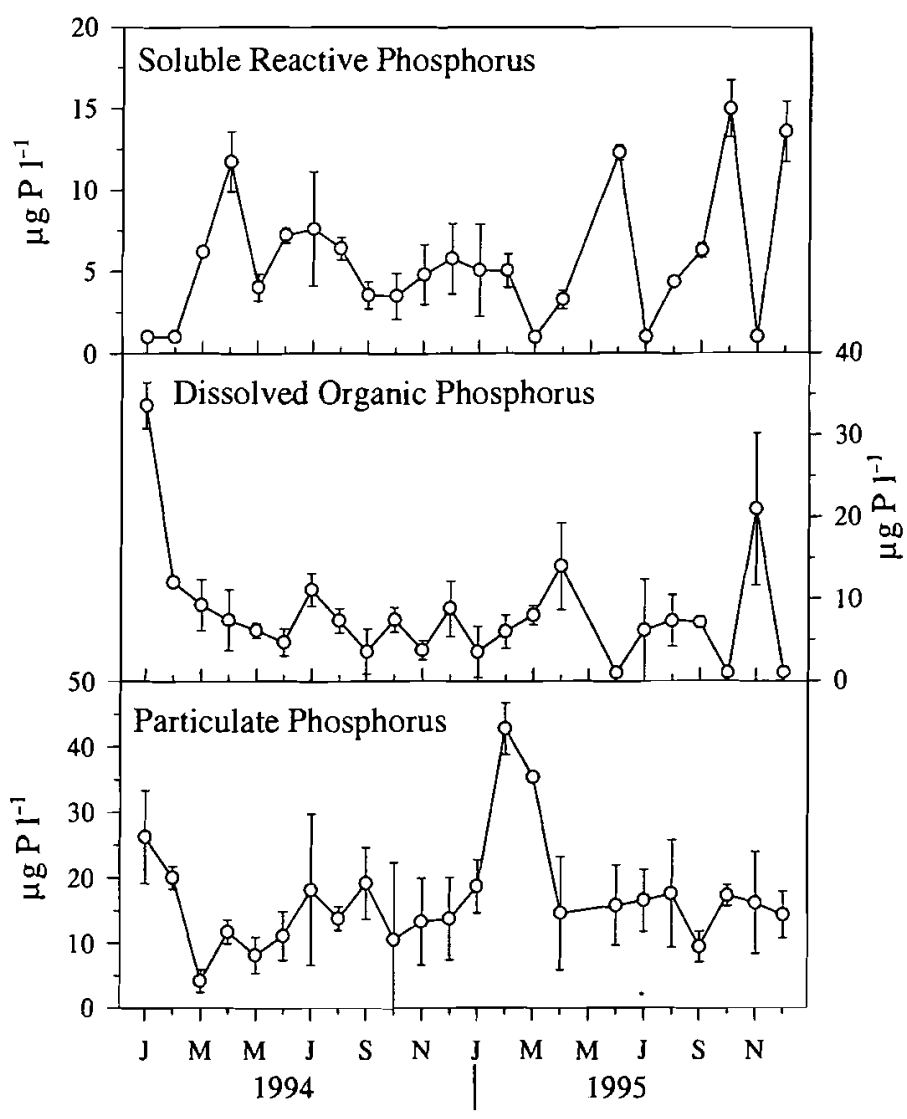

Fig. 4. Monthly mean phosphorus concentration ( $\pm 1 \mathrm{SD}$ ) for Apalachicola Bay over the 1994 to 1995 sampling period

tion of GOM SRP input occurred through St. George Sound. Integrated over the duration of the study period, St George Sound contributed $18 \%$ of the total SRP input to the estuary, while Indian Pass and Bob Sikes Cut contributed to $<2 \%$ of the total SRP input (Table 1). SRP input from the GOM, however, at times provided a significant fraction of the total SRP input to the estuary. For example in March 1995, October 1995, and December 1995, GOM SRP input to the estuary accounted for 69,59 , and $50 \%$, respectively, of the total SRP input to the estuary.

Minima in SRP export to the GOM occurred during winter and spring 1994. During the July 1994 flood-event, SRP export to the GOM reached a maximum of $5.5 \mathrm{mg} \mathrm{P} \mathrm{m}^{-2} \mathrm{~d}^{-1}$ (Fig. 5). During 1995, SRP export increased during the winter months to a maximum value in early spring. Of the total SRP export to GOM, during the and particulate phosphorus (Part $\mathrm{P}$ ) input to Apalachicola Bay and exchange at boundaries with Gulf of Mexico. Units are $\mathrm{mg} \mathrm{P} \mathrm{m}^{-2}$ integrated over $2 \mathrm{yr}$ study period. - : no contribution

\begin{tabular}{|lcccccc|} 
& \multicolumn{2}{c}{ SRP } & \multicolumn{2}{c}{ DOP } & \multicolumn{2}{c}{ Part P } \\
& Input & Export & Input & Export & Input & Export \\
\hline Apalachicola River & $1272 \pm 74$ & - & $1745 \pm 124$ & - & $4153 \pm 243$ & - \\
Indian Pass & 16 & 71 & 4 & 125 & 27 & 605 \\
West Pass & - & 550 & - & 963 & - & 3681 \\
Bob Sikes Cut & 14 & 54 & 25 & 66 & 64 & 253 \\
St. Georges Sound & $294 \pm 44$ & $235 \pm 30$ & $393 \pm 62$ & $252 \pm 50$ & $1129 \pm 303$ & $964 \pm 93$ \\
\hline
\end{tabular}


study period, $61 \%$ occurred through West Pass (Table 1). Integrated over the study period, SRP export through St. George Sound was similar in magnitude to input (Table 1). SRP export to GOM through Indian Pass and Bob Sikes Cut were approximately 4 times greater than input through those passes (Table 1).

\section{Dissolved organic phosphorus}

In contrast to SRP input, DOP input to the estuary was usually greater during winter high-flow periods than during other periods (Fig. 5). Following the winter highflow periods, DOP input to the estuary declined during the summer season (Fig. 5). Minimum DOP input $\left(0.2 \mathrm{mg} \mathrm{P} \mathrm{m}^{-2} \mathrm{~d}^{-1}\right)$ to the estuary was measured in June 1994 (Fig. 5). Similar to SRP input, maximum DOP input to the estuary (10.3 $\mathrm{mg} \mathrm{P} \mathrm{m}^{-2} \mathrm{~d}^{-1}$ ) was measured during the July 1994 flood (Fig. 5). Integrated over the study period, Apalachicola River and St. George Sound supplied 81 and $18 \%$, respectively, of the total DOP input to the estuary, while Indian Pass and Bob Sikes Cut combined accounted for the rest (Table 1).

DOP export to the GOM was lowest during the summer low river-flow periods (Fig. 5). Similar to SRP export, maximum DOP export $\left(7.6 \mathrm{mg} \mathrm{P} \mathrm{m}^{-2} \mathrm{~d}^{-1}\right)$ to the Gulf occurred during the July 1994 flood event (Fig. 2). Of the total DOP export to the GOM, 68 and $18 \%$ occurred through West Pass and St. George Sound, respectively (Table 1). Unlike minor SRP export to the GOM through Indian Pass and Bob Sikes Cut, DOP export through Indian Pass and Bob Sikes Cut accounted for $14 \%$ of the total DOP export to the GOM (Table 1).

\section{Particulate phosphorus}

The seasonal pattern in Part $\mathrm{P}$ input to Apalachicola Bay (Fig. 5) followed the river-discharge pattern (Fig. 2). During 1994, river discharge accounted for most of the water inflow to the estuary. Therefore, Part $\mathrm{P}$ input to the estuary occurred mainly through river input (Fig. 5). During March 1995 and the fall of 1995, however, when water input through the passes represented a significant amount of the total water inflow to the estuary (Fig. 2), Part $P$ input to the estuary through St. George Sound was significant (Fig. 5).

Integrated over the study period duration, Apalachicola River and St. George Sound accounted for 77 and $21 \%$ of the total Part P input to the estuary, respectively (Table 1). Exchange through Indian Pass and Bob Sikes Cut provided only a minor fraction of the total Part $\mathrm{P}$ input to the estuary (Table 1).

Maxima in Part $P$ export to the Gulf were measured during the July 1994 flood $\left(25.7 \mathrm{mg} \mathrm{P} \mathrm{m}^{-2} \mathrm{~d}^{-1}\right)$, and

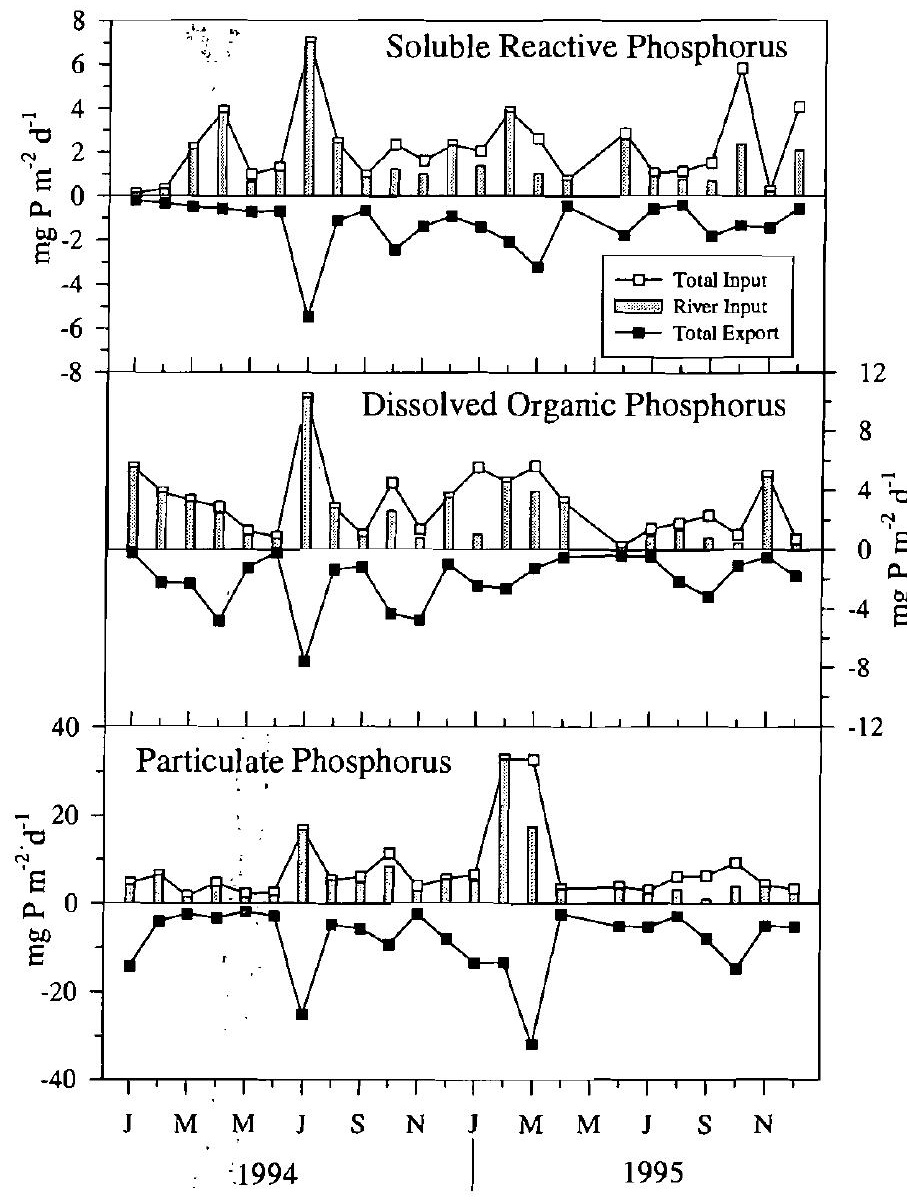

Fig. 5. Total (combined river \& GOM) input and river input to Apalachicola Bay and export to GOM for the 1994 and 1995

March 1995 (32.1 $\mathrm{mg} \mathrm{P} \mathrm{m}^{-2} \mathrm{~d}^{-1}$ ) when high water-input through St. George Sound combined with high riverflow forced estuarine water out to the GOM (Fig. 2). Of the total Part P export to the GOM, 67\% occurred through West Pass (Table 1). Part P export through St. George Sound was similar in magnitude to input. However, export through Indian Pass and Bob Sikes Cut exceeded input by an order of magnitude (Table 1).

\section{DISCUSSION}

\section{Phosphorus budget of Apalachicola Bay}

The US Geological Survey (USGS) estimated SRP and TP input rates for Apalachicola Bay from 1972 to 1990 (Frick et al. 1996). Mean SRP and TP input, based on concentrations measured at Chattahoochee, $170 \mathrm{~km}$ upstream of the river mouth, were $1.38 \mathrm{~g} \mathrm{P} \mathrm{m}^{-2} \mathrm{yr}^{-1}$ ( $\mathrm{n}=105$, range: 0.49 to 2.83 ) and $4.38 \mathrm{~g} \mathrm{P} \mathrm{m}^{-2} \mathrm{yr}^{-1}$ ( $n=153$, range: 1.75 to 8.38 ), respectively. The river 
SRP and TP input rates of $0.64 \pm 0.04$ and $3.59 \pm 0.14 \mathrm{~g}$ $\mathrm{P} \mathrm{m}^{-2} \mathrm{Yr}^{-1}$, respectively, determined in this study, are within the range of the USGS long-term mean input rates. The Apalachicola River accounted for $78 \%$ of the TP input to the estuary, with input from the GOM providing the remainder (Fig. 6). Over half (59\%) of the TP input to the estuary is in the particulate form, while the dissolved organic, and soluble reactive forms represent 24 and $17 \%$ of the TP input, respectively (Fig. 6).

Atmospheric deposition of phosphorus onto estuary surfaces accounts for only a few percent of the TP input to estuaries (Nixon et al. 1996). In this study, phosphorus input from direct atmospheric deposition on Apalachicola Bay was not measured. The longterm (1975 to 1984) mean monthly rainfall at the study site is $15.7 \mathrm{~cm}$ (Livingston et al. 1997). The water volume associated with the rainfall over the estuary is equivalent to $2 \%$ of the long-term mean river discharge. Total (wet + dry) phosphorus concentration measured at a site $130 \mathrm{~km}$ north of Apalachicola Bay is $10 \mu \mathrm{g} \mathrm{P}^{-1}$ (W. M. Landing, Florida Atmospheric Mercury Study, unpubl. data). Based on these values, phosphorus input through atmospheric deposition on the estuary proper (19 $\mathrm{mg} \mathrm{P} \mathrm{m}^{-2} \mathrm{yr}^{-1}$ ) accounts for $0.4 \%$ of the TP input to the estuary. In contrast to estuaries with a much larger surface area, such as Chesapeake Bay, where atmospheric deposition accounts for up to $7 \%$ of the diffuse and point phosphorus sources (Boynton et al. 1995), atmospheric contribution to the Apalachicola Bay phosphorus budget appears to be insignificant.

Based on Apalachicola Bay sedimentation rates (Hess 1995), percent sediment phosphorus content $(0.036 \%, \mathrm{~g} / \mathrm{g})$, and sediment dry density $\left(2.4 \mathrm{~g} \mathrm{~cm}^{-3}\right)$, $1.10 \pm 0.37 \mathrm{~g} \mathrm{P} \mathrm{m}^{-2} \mathrm{yr}^{-1}$ is lost to the sediments, while
$3.93 \mathrm{~g} \mathrm{P} \mathrm{m}^{-2} \mathrm{yr}^{-1}$ is exported to the GOM (Fig. 6). Phosphorus export to the GOM is dominated by the particulate form, representing $71 \%$ of the TP export, while the dissolved organic and soluble reactive forms represent 18 and $11 \%$ of the TP export, respectively (Fig. 6).

DOP represents a major fraction of the phosphorus pool in river water (Meybeck 1993) and in seawater (Jackson \& Williams 1985, Smith et al. 1986), and is a phosphorus source for the autotrophic and the microbial community (Orrett \& Karl 1987, Karl \& Yanagi 1997, Suzumura et al. 1998). On an annual scale, 58 and $36 \%$ of the SRP and DOP input to the estuary, respectively, were retained (Fig. 6). Therefore, net DOP $\left(0.38 \pm 0.12 \mathrm{~g} \mathrm{P} \mathrm{m}^{-2} \mathrm{yr}^{-1}\right)$ and net SRP $(0.35 \pm 0.06 \mathrm{~g} \mathrm{P}$ $\mathrm{m}^{-2} \mathrm{yr}^{-1}$ ) input to Apalachicola Bay constitute new phosphorus sources available for use by the estuarine primary producers and the microbial community.

Apalachicola Bay phytoplankton productivity was measured at the same time as nutrient samples were collected for this analysis (Mortazavi et al. 2000b, in this issue). Average primary production for the study period was $277 \mathrm{~g} \mathrm{C} \mathrm{m}^{-2} \mathrm{yr}^{-1}$. Carbon productivity values were converted to $\mathrm{P}$ demand $\left(6.75 \mathrm{~g} \mathrm{P} \mathrm{m}^{-2} \mathrm{yr}^{-1}\right)$ with the Redfield (1958) ratio (106C:1P). Assuming that all the DOP and SRP retained in the estuary is made available to the primary producers, $11 \%$ of annual phytoplankton phosphorus demand is supplied by 'new' phosphorus.

Benthic flux N:P ratios are close to $16: 1$ in 5 of the 7 GOM estuaries for which data are available (Twilley et al. 1999). Based on nitrogen remineralization rates measured in Apalachicola Bay (Mortazavi et al. 2000a) and a 16:1 N:P ratio, the benthos could provide $1 \mathrm{~g} \mathrm{P} \mathrm{m}^{-2} \mathrm{yr}^{-1}$ to the primary producers in the water column. Therefore, benthic remineralization could
River Input

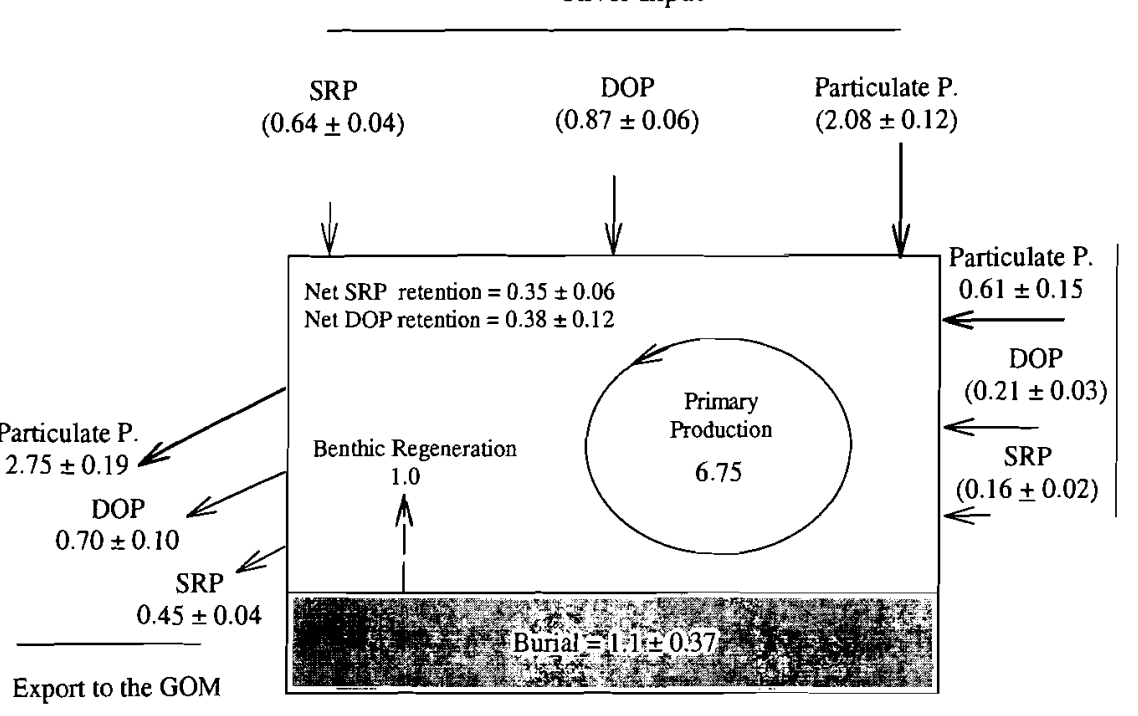

Fig. 6. Apalachicola Bay annual phosphorus budget. Units are in $\mathrm{g} \mathrm{P} \mathrm{m}^{-2} \mathrm{yr}^{-1}( \pm 1 \mathrm{SD})$. Burial was estimated from sedimentation rate $\left(4.2 \pm 1.4 \mathrm{~mm} \mathrm{yr}^{-1}\right.$; Hess 1995), sediment phosphorus content of $0.036 \% \mathrm{~g} / \mathrm{g}$, sediment dry density of $2.4 \mathrm{~g} \mathrm{~cm}^{-3}$, and porosity of 0.70 (Mortazavi unpublished data). Benthic remineralization was estimated from benthic nitrogen flux (Mortazavi et al. 2000a) converted to phosphorus flux with 16:1 N:P remineralization ratio (Twilley et al. 1999). Annual (TP) input = $4.57 \pm 0.21$, export plus sedimentation $=5.00 \pm 0.43$. Annual TP budget is balanced to within $9 \%$ of the TP input. SRP: soluble reactive phosphorus; DOP: dissolved organic phosphorus 
provide $15 \%$ of the annual phytoplankton phosphorusdemand in Apalachicola Bay. This is similar to the benthic contribution in Mobile Bay, a river-dominated estuary located west of Apalachicola Bay, where $23 \%$ of the water-column phosphorus-demand is provided by benthic regeneration (Cowan et al. 1996). Because 11 and $15 \%$ of the phytoplankton phosphorus-demand in Apalachicola Bay are supplied by new phosphorus input to the estuary and benthic regeneration, respectively, water-column regeneration must supply the remaining $74 \%$.

The greatest uncertainty associated with the phosphorus budget of Apalachicola Bay arises from SRP measurements at the river and the seaward boundary

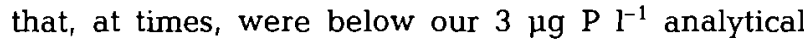
detection limit (Figs. $3 \& 4$ ). To provide continuity in calculations with time-series data, we employed a data-fill method, whereby values below detection limit were set equal to $1 \mu \mathrm{g} \mathrm{P} \mathrm{l}^{-1}$. We compared the results of this method with the results achieved by replacing SRP values below detection limit with $0.2 \mu \mathrm{g} \mathrm{Pl}^{-1}$. This procedure allows determination of the effects of the datafill method on the phosphorus-budget calculations. The results indicated that net SRP input to the estuary increased by $8 \%$ when values below detection limit were increased from 0.2 to $1 \mu \mathrm{g} \mathrm{P} \mathrm{l}^{-1}$. This increase is within the sampling error associated with the budget in Fig. 6.

\section{Phosphorus input to and export from estuaries}

Nutrient budgets for estuaries and coastal ecosystems are becoming available as concern about the impact of nutrient input on coastal ecosystems increases (Boynton et al. 1995, Nixon 1995). Phosphorus input to the GOM estuaries varies by an order of magnitude, with input maxima occurring in Mississippi delta estuaries; e.g., phosphorus input to Fourleague Bay is $12 \mathrm{~g} \mathrm{P} \mathrm{m}^{-2} \mathrm{yr}^{-1}$ (Twilley et al. 1999). Phosphorus input minima occur in GOM estuaries with low freshwater input; e.g., Ochlockonee Bay, a coastal plain estuary situated $40 \mathrm{~km}$ east of Apalachicola Bay, receives freshwater from the Ochlockonee River at a mean discharge rate of $27 \mathrm{~m}^{3} \mathrm{~s}^{-1}$ (Fu \& Winchester 1994). TP input to Ochlockonee Bay, $1.55 \mathrm{~g} \mathrm{P} \mathrm{m}^{-2} \mathrm{yr}^{-1}$ (Kaul \& Froelich 1984), is among the lowest input rate to a GOM estuary (Twilley et al. 1999). Compared to other GOM estuaries, phosphorus input to Apalachicola Bay occurs in moderate quantities.

Northern US estuaries have a smaller TP input range than GOM estuaries. For example, TP input to Chesapeake Bay is $1.2 \mathrm{~g} \mathrm{P} \mathrm{m}^{-2} \mathrm{yr}^{-1}$ (Boynton et al. 1995), input to Narragansett Bay is $3.6 \mathrm{~g} \mathrm{P} \mathrm{m}^{-2} \mathrm{yr}^{-1}$, and input to Delaware Bay is $4.9 \mathrm{~g} \mathrm{P} \mathrm{m}^{-2} \mathrm{yr}^{-1}$ (Nixon et al. 1996).
Sewage input accounts for 27,35 , and $45 \%$ of the TP input to Chesapeake, Narragansett, Potomac, respectively (Nixon et al. 1996). Combined TP input from Apalachicola River and the GOM to the estuary (4.57 \pm $0.21 \mathrm{~g} \mathrm{P} \mathrm{m}^{-2} \mathrm{yr}^{-1}$ ) is comparable to those for northern US estuaries. In contrast to northern US estuaries, however, the Apalachicola River watershed is considered pristine (Livingston 1984), and sewage input in the Apalachicola portion of the ACF is insignificant (Fu \& Winchester 1994)

Phosphorus-transport processes differ among coastal plain estuaries and between coastal plain and bar-built estuaries. In Narragansett Bay (Weisberg \& Sturges 1976, Wong \& Garvine 1984) and Delaware Bay (Weisberg \& Sturges 1976, Wong \& Garvine 1984), net water-velocities are directed seaward at lower depths. Therefore, phosphorus is exported, but not imported, at the seaward boundary of those estuaries (Nixon et al. 1996). Chesapeake Bay is characterized by 2-layer gravitational circulation, with net landward transport in the bottom layer (Boynton et al. 1995). Between 9 and $37 \%$ of the combined terrestrial and atmospheric TP input to Chesapeake Bay and its tributaries is imported at the seaward boundary (Boynton et al. 1995). The bar-built Apalachicola Bay exhibits a marked difference from drowned river-valley estuaries. Phosphorus carried by GOM water enters Apalachicola Bay mainly at the eastern boundary through St. George Sound, at a rate equivalent to $27 \%$ of the annual river phosphorus input (Table 1, Fig. 6).

Nutrient export from an estuary is predicted to decrease as the water residence-time increases (Nixon et al. 1996). However, phosphorus export and residence time in the Nixon et al. data set are not as highly correlated as the relationship between nitrogen export and residence time. The fraction of phosphorus input exported from Apalachicola Bay $(87 \%)$ is similar to the export fraction for (e.g.) Narragansett Bay $(80 \%)$ and Delaware (83\%) (Nixon et al. 1996). Residence times of the latter 2 estuaries exceed that of Apalachicola Bay (mean $=0.2$ mo (Mortazavi et al. 2000a) by 5 and 15 times, respectively (Nixon et al. 1996).

The input:export ratio of nitrogen and phosphorus for estuaries is affected by sedimentation and by chemical reactions, which differ for the 2 elements. Particulate phosphorus is the main constituent of the world river phosphorus pool (Meybeck 1982), and represents a significant fraction, and the largest phosphorus input source, to estuaries (Kaul \& Froelich 1984, Boynton et al. 1995, Nixon et al. 1995) and to the world ocean (Meybeck 1993). For example, $61 \%$ of the phosphorus input to the Ems estuary is in particulate form, while dissolved organic and soluble reactive forms account for 13 and $26 \%$ of TP input (van Beusekom \& de Jonge 1998). Part P retention within an estuary depends on 
input rates, transport rates through the estuary, and sediment-accumulation rates, which differ between estuaries (McKee \& Baskaran 1999). In the estuarine water-column, reactive phosphate is released from suspended particulates according to a buffering mechanism which maintains a nearly constant water-column SRP concentration (Froelich 1988), a chemical property of Part $P$ that is not evident in particulate nitrogen.

Phosphorus limitation of phytoplankton production and biomass is a common feature in freshwater environments (Howarth 1988), whereas nitrogen is the nutrient most frequently limiting phytoplankton growth in estuarine and coastal regions (Ryther \& Dunstan 1971, Howarth 1988, Oviatt et al. 1995). However, phosphorus or phosphorus and nitrogen co-limitation have been reported in estuaries during certain seasons or at different locations within the same estuary ( $D^{\prime}$ Elia et al. 1986, Fisher et al. 1992, Flemer et al. 1998).

Phytoplankton productivity in Apalachicola Bay is limited by phosphorus in areas of the estuary (within and near the river plume) and at time periods (mainly winter) when salinity is low. When salinity is high, nitrogen limits phytoplankton productivity (Myers \& Iverson 1981, Fulmer 1997). A nitrogen budget indicated that DON input was balanced by export from the estuary (Mortazavi et al. 2000a). However, in contrast to DON, the results of this phosphorus budget indicate that $36 \%$ of DOP input to the estuary is retained, and could potentially be used by the microbial community and primary producers.

Acknowledgements. This research was supported by a grant awarded to R.L.I. and W.M.L. from the Northwest Florida Water Management District and the Florida Department of Environmental Protection. Many thanks to R. Powell, C. Bailey, L. Edmiston and the staff of the Apalachicola National Estuarine Research Reserve for their assistance during sampling. We would like to thank Glen Laird at the FSU Statistical Consulting Center for help with the error analyses. We express our appreciation to Graham Lewis and 3 anonymous reviewers for comments on a previous version of this manuscript.

\section{LITERATURE CITED}

Bianchi TS, Pennock JR, Twilley RR (1999) Biogeochemistry of Gulf of Mexico estuaries: implications for management. In: Bianchi TS, Pennock JR, Twilley RR (eds) Biogeochemistry of Gulf of Mexico estuaries. John Wiley \& Sons, New York, p 407-421

Blumberg AF, Goodrich DM (1990) Modeling of windinduced destratification in Chesapeake Bay. Estuaries 13: 236-249

Blumberg AF, Herring $\mathrm{J}$ (1987) Circulation modeling using orthogonal curvilinear coordinates. In: Nihoul JCJ, Jamart BM (eds) Three-dimensional models of marine and estuarine dynamics. Elsevier, Amsterdam, p 55-58
Blumberg AF, Mellor GL (1980) A coastal ocean numerical model. Hamburg. In: Sundermann J, Holz KP (eds) Mathematical modeling of estuarine physics. Proceedings of the International Symposium, 24-26 August, 1978. SpringerVerlag, Berlin, p 203-214

Blumberg AF, Mellor GL (1987) A description of a threedimensional coastal circulation model. In: Heaps NS (ed) Three-dimensional coastal ocean models. Coastal and Estuarine Sciences Vol. 4. American Geophysical Union, Washington DC, p 1-16

Boynton WR, Garber JH, Summers R, Kemp WM (1995) Inputs, transformation, and transport of nitrogen and phosphorus in Chesapeake Bay and selected tributaries. Estuaries 18:285-314

Cowan JLW, Pennock JR, Boynton WR (1996) Seasonal and interannual patterns of sediment-water nutrient and oxygen fluxes in Mobile Bay, Alabama (USA): regulating factors and ecological significance. Mar Ecol Prog Ser 141: $229-245$

D'Elia CF, Sanders JG, Boynton WR (1986) Nutrient enrichment studies in a coastal plain estuary: phytoplankton growth in large-scale, continuous cultures. Can J Fish Aquat Sci 43:397-406

Fisher TR, Peele ER, Ammerman JW, Harding LW (1992) Nutrient limitation of phytoplankton in Chesapeake Bay. Mar Ecol Prog Ser 82:51-63

Flemer DA, Livingston RJ, McGlynn SE (1998) Seasonal growth stimulation of sub-temperate estuarine phytoplankton to nitrogen and phosphorus: an outdoor microcosm experiment. Estuaries 21:145-159

Frick EA, Buell GR, Hopkins EE (1996) Nutrient sources and analysis of nutrient water-quality data, ApalachicolaChattahoochee-Flint River basin, Georgia, Alabama, and Florida, 1972-90. Wat Resour Invest Rep US Geol Surv, 96-4101:1-120

Froelich P, Bender M, Luedtke N, Heath G, Devries T (1982) The marine phosphorus cycle. Am J Sci 282:474-511

Froelich PN (1988) Kinetic control of dissolved phosphate in natural rivers and estuaries: a primer on the phosphate buffer mechanism. Limnol Oceanogr 33:649-668

Fu JM, Winchester JW (1994) Sources of nitrogen in three watersheds of northern Florida, USA: mainly atmospheric deposition. Geochim Cosmochim Acta 58:1581-1590

Fulmer JM (1997) Nutrient enrichment and nutrient input to Apalachicola Bay, Florida. MSc thesis. Florida State University, Tallahassee

Galperin B, Kantha LH, Hassid S, Rosati A (1988) A quasiequilibrium turbulent energy model for geophysical flows. J Atmos Sci 45:55-62

Galperin B, Mellor GL (1990) A time-dependent, 3-dimensional model of the Delaware Bay and River system. 2. 3 dimensional flow-fields and residual circulation. Estuar Coast Shelf Sci 31:255-281

Greenberg AE, Clesceri LS, Eaton AD (1992) Standard methods for the examination of water and wastewater. American Public Health Association, Washington, DC

Hess DW (1995) A study of storm and anthropogenic effects on estuarine sedimentation, Apalachicola Bay, Florida. MSc thesis, Florida State University, Tallahassee

Howarth R (1988) Nutrient limitation of net primary production in marine ecosystems. A Rev Ecol Syst 19:89-110

Huang W, Jones WK (1997) Three-dimensional modeling of circulation and salinity for the low river flow season in Apalachicola Bay, FL. Northwest Florida Water Management District Water Resources, Havana, Florida (Spec Rep No. 97-1)

Humborg $C$ (1997) Primary productivity regime and nutrient 
removal in the Danube estuary. Estuar Coast Shelf Sci 45 579-589

Jackson GA, Williams PM (1985) Importance of dissolved organic nitrogen and phosphorus to biological nutrient cycling. Deep-Sea Res 32:223-235

Jones WK, Huang W (1996) Modeling changing freshwater delivery to Apalachicola Bay, FL. In: Spauling ML, Cheng RT (eds) Estuarine and coastal modeling: Proceedings of the 4th International Conference. American Society of Civil Engineering, New York, p 116-127

Karl DM, Yanagi K (1997) Partial characterization of the dissolved organic phosphorus pool in the oligotrophic North Pacific Ocean. Limnol Oceanogr 42:1398-1405

Kaul LW, Froelich PN (1984) Modeling estuarine geochemistry in a simple system. Geochim Cosmochim Acta 48: $1417-1433$

Livingston RJ (1984) The ecology of the Apalachicola Bay system: an estuarine profile. U.S. Fish and Wildlife Services, Washington, DC (FWS/OSB-82/05)

Livingston RJ, Niu X, Lewis III FG, Woodsum GC (1997) Freshwater input to a gulf estuary: long-term control of trophic organization. Ecol Applics 7:227-299

McCracken DD, Dorn WS (1964) Numerical methods and fortran programming. John Wiley \& Sons, New York

McKee B, Baskaran M (1999) Sedimentary processes of Gulf of Mexico Estuaries. In: Bianchi TS, Pennock JR, Twilley RR (eds) Biogeochemistry of Gulf of Mexico estuaries. John Wiley \& Sons, New York, p 63-85

Mellor GL, Yamada T (1982) Development of a turbulence closure model for geophysical fluid problems. Rev Geophys 20:851-857

Meybeck M (1982) Carbon, nitrogen, and phosphorus transport by world rivers. Am J Sci 282:401-450

Meybeck M (1993) C, N, P and S in rivers: from sources to global inputs. Interactions of $C, N, P$ and $S$ biogeochemical cycles and global change. Springer-Verlag, Berlin, 163-193

Montgomery DC (1991) Design and analysis of experiments. John Wiley \& Sons, New York

Mortazavi B, Iverson RL, Huang W, Lewis GF, Caffrey JM (2000a) Nitrogen budget of Apalachicola Bay: a bar-built, subtropical estuary in the northeastern Gulf of Mexico. Mar Ecol Prog Ser 195:1-14

Mortazavi B, Iverson RL, Landing WM, Huang W, Lewis FG (2000b) Control of phytoplankton production and biomass in a river-dominated estuary: Apalachicola Bay, Florida, USA. Mar Ecol Prog Ser 198:19-31

Myers VB, Iverson RI (1981) Phosphorus and nitrogen limited phytoplankton productivity in northeastern Gulf of Mexico coastal éstuaries. In: Neilson BJ, Cronin LE (eds) Estuaries and nutrients. Humana Press, Clifton, NJ, p 569-582

Nixon SW (1987) Chesapeake Bay nutrient budgets - a reassessment. Biogeochemistry 4:77-90

Nixon SW (1995) Coastal marine eutrophication: a definition, social causes, and future concerns. Ophelia 41:199-219

Nixon SW, Ammerman JW, Atkinson LP, Berounsky VM, Billen G, Boicourt WC, Boynton WR, Church TM, Ditoro DM, Elmgren R, Garber JH, Giblin AE, Jahnke RA, Owens NJP, Pilson MEQ, Seitzinger SP (1996) The fate of nitrogen and phosphorous at the land-sea margin of the North Atlantic Ocean. Biogeochemistry 35:141-180
Nixon SW, Granger SL, Nowicki BL (1995) An assessment of the annual mass balance for carbon, nitrogen, and phosphorus in Narragansett Bay. Biogeochemistry 31:15-61

Nixon SW, Pilson MEQ (1983) Nitrogen in estuaries and coastal marine environments. In: Carpenter EJ, Capone DG (eds) Nitrogen in the marine environments. Academic Press, New York, p 565-648

Orrett K, Karl DM (1987) Dissolved organic phosphorus production in surface seawaters. Limnol Oceanogr 32: 383-395

Oviatt C, Doering P, Nowicki B, Reed L, Cole J, Frithsen J (1995) An ecosystem-level experiment on nutrient limitation in temperate coastal marine environments. Mar Ecol Prog Ser 116:171-179

Pennock JR, Boyer JN, Herrera-Silveira JA, Iverson RL, Whitledge TE, Mortazavi B, Comin FA (1999) Nutrient behavior and phytoplankton production in Gulf of Mexico estuaries. In: Bianchi TS, Pennock JR, Twilley RR (eds) Biogeochemistry of Gulf of Mexico estuaries. John Wiley \& Sons, New York, p 109-162

Redfield AC (1958) The biological control of chemical factors in the environment. Am Sci 46:205-221

Ryther $\mathrm{JH}$, Dunstan WM (1971) Nitrogen, phosphorous, and eutrophication in the coastal marine environments. Science 171:1008-1013

Schlesinger WH (1997) Biogeochemistry. An analysis of global change. Academic Press, New York

Seitzinger SP, Sanders RW (1997) Contribution of dissolved organic nitrogen from rivers to estuarine eutrophication. Mar Ecol Prog Ser 159:1-12

Smith SV, Kimmerer WJ, Walsh TW (1986) Vertical flux and biogeochemical turnover regulate nutrient limitation of net organic production in the North Pacific gyre. Limnol Oceanogr 31:161-167

Strickland JD, Parsons TR (1972) A practical handbook of seawater analysis, 2nd edn. Bull Fish Res Bd Can 167:1-310

Suzumura M, Ishikawa K, Ogawa H (1998) Characterization of dissolved organic phosphorus in coastal seawater using ultrafiltration and phosphohydroiytic enzymes. Limnol Oceanogr 43:1553-1564

Tréguer $\mathrm{P}$, Nelson DM, Van Bennekom AJ, DeMaster DJ, Leynaert A, Quéguiner B (1995) The silica balance in the world ocean: a reestimate. Science 268:375-379

Twilley RR, Cowan J, Miller-Way T, Montagna P, Mortazavi B (1999) Benthic nutrient fluxes in selected estuaries in the Gulf of Mexico. In: Bianchi TS, Pennock JR, Twilley RR (eds) Biogeochemistry of Gulf of Mexico estuaries. John Wiley \& Sons, New York, p 163-209

van Beusekom JEE, de Jonge VN (1998) Retention of phosphorus and nitrogen in the Ems estuary. Estuaries 21: 527-539

Weisberg R, Sturges W (1976) Velocity observations in the west passage of Narragansett Bay: a partially mixed estuary. J Phys Oceanogr 6:345-354

Wilber DH (1992) Association between freshwater inflows and oyster productivity in Apalachicola Bay, Florida. Estuar Coast Shelf Sci 35:179-190

Wong KC, Garvine RW (1984) Observations of wind-induced, subtidal variability in the Delaware estuary. $\mathrm{J}$ Geophys Res 89:589-597

Submitted: July 29, 1999; Accepted: December 23, 1999 Proofs received from author(s): May 19, 2000 